\title{
TOWARDS A PRECISE MODELLING OF THE EL SALVADOR FAULT ZONE USING GEODETIC TECHNIQUES
}

\author{
HACIA UN MODELADO PRECISO DE LA ZONA DE FALLA DE EL SALVADOR UTILIZANDO TÉCNICAS \\ GEODÉSICAS \\ Juan J. Portela-Fernández ${ }^{\mathrm{a},{ }^{,},}$, Alejandra Stallera, Marta Béjar-Pizarro ${ }^{\mathrm{b}}$ \\ ${ }^{\text {a }}$ Departamento de Ingeniería Topográfica y Cartografía, Universidad Politécnica de Madrid, C/ Mercator 2, 28031 Madrid, Spain. \\ jj.portela@upm.es; a.staller@upm.es \\ b Geohazards InSAR Laboratory and Modeling Group (InSARlab), Geoscience Research Department, Geological Survey of Spain
} (IGME), Alenza 1, 28003 Madrid, Spain. m.bejar@igme.es

\begin{abstract}
:
The El Salvador Fault Zone (ESFZ) comprises a set of a strike-slip faults, extending through the Central American Volcanic Arc within El Salvador, where the Cocos plate subducts under the Caribbean plate. These structures act as a boundary between the forearc sliver and the western margin of the Chortís block, accommodating the relative movement between them. The ESFZ has been responsible for several shallow, destructive earthquakes in El Salvador, thus posing a serious threat for millions of inhabitants. Understanding its seismic potential and the behaviour of its different segments results of great importance for the assessment and mitigation of seismic risk in the region. Geodetic techniques, such as GNSS and InSAR, are useful tools for measuring surface deformation related to tectonic activity. We are in the process of updating and densifying the existing GNSS velocity field in EI Salvador, aiming to characterise the individual faults in the region by determining their slip rates and locking depth. Additionally, we will process InSAR data, trying to obtain a continuous measurement of the interseismic deformation. The combination of this information with other data (e.g. seismological and geological) through kinematic models will allow us to better understand the factors controlling the seismogenic behaviour of the ESFZ faults, evaluate their seismic potential and improve the seismic hazard assessment.
\end{abstract}

Key words: geodesy, active tectonics, kinematic modelling, GNSS, El Salvador

\section{Resumen:}

La Zona de Falla de El Salvador (ESFZ) comprende un conjunto de fallas de deslizamiento extendiéndose a través del Arco Volcánico Centroamericano en El Salvador, donde la placa del Coco subduce bajo la placa Caribe. Estas estructuras actúan como límite entre el antearco volcánico y el margen occidental del bloque Chortís, acomodando el movimiento relativo entre ambos. La ESFZ ha sido responsable de varios terremotos someros destructivos en El Salvador, lo que representa una seria amenaza para millones de habitantes. Comprender su potencial sísmico y el comportamiento de sus diferentes segmentos resulta de gran importancia para la evaluación y mitigación del riesgo sísmico en la región. Las técnicas geodésicas, como GNSS e InSAR, son herramientas útiles para medir la deformación de la superficie relacionada con la actividad tectónica. Actualmente estamos actualizando y densificando el campo de velocidad GNSS existente en El Salvador, con el objetivo de caracterizar las fallas individuales en la región, determinando sus tasas de deslizamiento y profundidad de bloqueo. Además, procesaremos datos InSAR, tratando de obtener una medición continua de la deformación intersísmica. La combinación de esta información con otros datos (por ejemplo, sismológicos y geológicos) a través de modelos cinemáticos nos permitirá comprender mejor los factores que controlan el comportamiento sismogénico de las fallas de ESFZ, evaluar su potencial sísmico y mejorar la evaluación de la amenaza sísmica.

Palabras clave: geodesia, tectónica activa, modelización cinemática, GNSS, EI Salvador

\section{Introduction}

The country of El Salvador lies on a region with high seismic activity. On the past years, several destructive earthquakes have caused major damage to both its inhabitants and infrastructure, particularly those of January (Mw 7.7) and February (Mw 6.6) of 2001 (Martínez-Díaz et al. 2004a). Moreover, secondary effects triggered by earthquakes, primarily landslides, are common in the region (e.g. Jibson et al. 2004).
El Salvador is located on a convergent tectonic margin, where the Cocos plate subducts under the Caribbean plate. The subduction interface is thought to be loosely coupled and advancing orthogonally with respect to the trench (Alvarado et al. 2011). However, several studies identify a differential movement between the Chortís block, located to the north of the Central American Volcanic Arc (CAVA), and the volcanic forearc sliver (CAFA) to the south, which cannot be explained by the Cocos subduction (e.g. Alvarado et al. 2011; ÁlvarezGómez et al. 2019). The cause of the CAFA drift is not yet clear. While several studies suggest that the subduction

*Corresponding Author: Juan J. Portela-Fernández, jj.portela@upm.es 
of the Cocos Ridge and the higher interface coupling off Costa Rica is responsible for pushing the forearc towards the northwest (Kobayashi et al. 2014; Lafemina et al. 2009), others point to the pinning of the forearc in Guatemala by the westward movement of the North American plate (Álvarez-Gómez et al. 2008; Rodríguez et al. 2009). A combined effect of both causes has also been proposed (Álvarez-Gómez et al. 2019).

In El Salvador, the forearc sliver escapes towards the northwest at a rate of approximately $12 \mathrm{~mm} / \mathrm{yr}$ with respect to the Chortís block (Álvarez-Gómez et al. 2019). The differential movement between the two blocks is accommodated by the El Salvador Fault Zone (ESFZ), comprised by a set of right-lateral strike-slip faults extending through the volcanic arc with a E-W/NW direction (Martínez-Díaz et al. 2004b). Tectonic depressions lie between the fault traces, as in San Salvador (Garibaldi et al. 2016).

The earthquakes originated on faults within the volcanic arc pose a great danger to the population of El Salvador, due to their shallow depths, proximity to urban areas and frequency (Legrand et al. 2020). Understanding the kinematics and behaviour of the individual faults is key for assessing the seismic hazard in the country. Geodetic techniques, such as GNSS and InSAR, have become relevant tools for assessing surface deformation, thus providing valuable information for seismic hazard analysis (Elliott et al. 2016).

One simple way to characterise a fault is through its slip rate, i.e., the difference of velocity at which the two sides of the fault are moving (or the displacement deficit that the fault is accumulating if completely locked). This quantity can be obtained from geodetic measurements of the movement of the ground (in which case we speak of short-term slip rates) or geological/geomorphological observations (long-term slip rates).

Several tectonic studies have been carried out in El Salvador (e.g. Alonso-Henar et al. 2015; Canora et al. 2012), many incorporating GNSS observations (e.g. Alvarado et al. 2011; Ellis et al. 2018; Legrand et al. 2020; Staller et al. 2016). Although most of these studies have a regional scale, covering broader areas in Central America (Alvarado et al. 2011; Correa-Mora et al. 2009; Ellis et al. 2018; Ellis et al. 2019; Lyon-Caen et al. 2006; Rodríguez et al. 2009), some focus on the ZFES (Canora et al. 2014; Garibaldi et al. 2016; Staller et al. 2016), or specific segments (Legrand et al. 2020). In contrast to the relative abundance of GNSS studies, InSAR studies on the area are very limited in number, consisting mostly of regional-scale volcanic studies (e.g. Ebmeier et al. 2013; Reath et al. 2019) or local studies (Chavez Hernandez et al. 2020). New GNSS observations within the area, supported by an increasing number of available SAR images, may shed light on the kinematics of the individual faults within the ESFZ.

The Guaycume fault (Fig. 1), located roughly $10 \mathrm{~km}$ from San Salvador, is one of the main dextral strike-slip features within the ESFZ, presenting a clear geomorphological expression (Martínez-Díaz et al., 2021). It has been proposed as a possible source for the destructive Mw 6.4 1917 El Salvador earthquake (AlonsoHenar et al. 2018). However, its precise behaviour is far from being known. The slip rates assigned in past studies vary significantly: Staller et al. (2016) estimate a slip rate of $8 \mathrm{~mm} / \mathrm{yr}$, while Legrand et al. (2020) suggest that most of the deformation is accumulating further south.

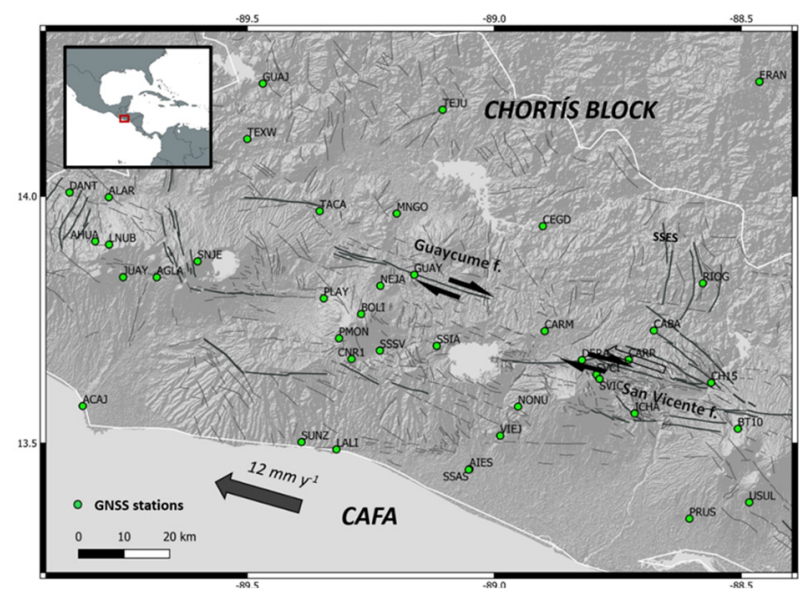

Figure 1: Context of the study area. Green dots represent the GNSS stations used in this study. Dark grey lines show the main faults within the ESFZ, while light grey lines represent minor structures (Martínez-Díaz et al. 2021). Double black arrows show the dextral behaviour of the main faults. The bigger grey arrow shows the approximate relative movement of the CAFA (Central American Volcanic Forearc) with respect to the Chortís block.

New GNSS stations installed on the area (Fig. 1) will help to improve the knowledge of the regional kinematics. Here we present the preliminary results on the characterisation of the Guaycume fault, with a methodology that we aim to extend to the entire El Salvador.

\section{Data}

We are processing GNSS observations from 2003 to 2021 in all available stations throughout El Salvador. We are also processing permanent GNSS stations located in North, Central and South America, as well as in the Caribbean, in order to link our solutions to the global reference frame ITRF2014 (Altamimi et al. 2014). Our primary sources are listed below:

1) ZFESNet (Staller et al. 2008; Staller et al. 2016) continuous and campaign sites.

2) UNAVCO permanent stations (UNAVCO 2020).

3) UNAVCO old campaigns in El Salvador and Honduras (DeMets 2004; DeMets 2007a; DeMets 2007b; DeMets 2008a; DeMets 2008b; DeMets 2009; DeMets 2011a; DeMets 2011b; DeMets and Tikoff 2015a; DeMets and Tikoff 2015b; DeMets and Tikoff 2015c; DeMets and Tikoff 2015d; DeMets and Tikoff 2015e).

4) IGS permanent stations (International GNSS service 2020)

5) CORS permanent stations (National Geodetic Survey 2017).

We take advantage of the densification of the ZFESNet over the last years and the conversion of some of the campaign sites to permanent stations. We are also including old GNSS campaigns in El Salvador and Honduras available at UNAVCO, in order to make our solutions more consistent and extend the area covered by GNSS measurements. 
In a preliminary stage, aiming to characterise the Guaycume fault, we have collected seismic data since 1915 from the International Seismological Centre (ISC 2021), filtering to shallow seismicity, i.e., with depths under $30 \mathrm{~km}$. We have obtained more than 8600 events up to Mw 7.1.

Other data, such as geomorphological and geological data, will be incorporated in the future.

\section{Methodology}

We process the GNSS (GPS + GLONASS) observations using Bernese 5.2 (Dach et al. 2015) in static, relative mode, obtaining a daily positioning solution for each station, referred to ITRF2014. We then correct the position time series of the campaign stations from the coseismic offsets attributable to the $2009 \mathrm{Mw} 7.3$ Swan Island, $2012 \mathrm{Mw} 7.3 \mathrm{El}$ Salvador and $2012 \mathrm{Mw} 7.4$ Champerico earthquakes, applying the values estimated by Ellis et al. (2018). We compute the linear velocity for each station and its uncertainty using the software SARI (Santamaría-Gómez 2019), identifying instrumental and coseismic offsets, removing the stational, annual signal and estimating noise levels in the continuous time series. Finally, we compute the velocities with respect to a fixed Caribbean plate, regarding the NNR-MORVEL56 pole (Argus et al. 2011).

Since we are focusing at first on the Guaycume fault, we project the horizontal GNSS velocities -and their uncertainties- in a profile of the fault (with an azimuth of $110^{\circ}$ ), obtaining the fault-parallel and fault-orthogonal velocities. We then fit a simple dislocation model for a strike slip fault to the fault-parallel velocities, following Savage and Burford (1973), as in Eq. (1):

$\mathrm{v}=\frac{f}{\pi} \operatorname{atan}\left(\frac{\mathrm{x}}{d}\right)$

Where:

$$
\begin{aligned}
& \mathrm{v}=\text { Fault-parallel velocity } \\
& f=\text { Far-field velocity } \\
& \mathrm{x}=\text { Distance to fault } \\
& d=\text { Locking depth }
\end{aligned}
$$

The fault-parallel velocity and the distance to the fault correspond to our pairs of observations, while the far-field velocity is usually related to the slip rate of the fault. The locking depth is assumed as shallow, as it is likely in volcanic arcs (Canora 2011; Correa-Mora et al. 2009).

We tried to fit (with a least square adjustment) three different models:

1) Setting the Guaycume fault as the only structure accumulating deformation.

2) Defining a single fault accumulating the deformation, but with unconstrained position, and setting the locking depth to a probable value of $9 \mathrm{~km}$.

3) Defining two main features accumulating deformation at the northern and southern borders of the San Salvador graben (respectively, the Guaycume fault and a non-constrained structure to the south).

\section{Preliminary results}

The Guaycume fault lies on an aseismic area, regarding the ISC catalogue. This could be due to either a strong locking of the fault or an aseismic behaviour. The cortical seismicity is clustered mainly in the San Salvador graben.

The obtained velocity field on the area is consistent with the previously published velocities (e.g. Ellis et al. 2018; Staller et al. 2016). Approximately $12 \mathrm{~mm} / \mathrm{yr}$ of accumulated deformation are detected between the north (Southern Honduras) and south (the Pacific coast) of the study area, coherently with the relative forearc movement estimated by Álvarez-Gómez et al. (2019).

The three models that we fit to the fault-parallel velocity profile (Fig. 2) show different performances:

1) The model assuming that the Guaycume fault is the only structure accomodating the movement of the forearc does not fit to the observations. The model does not converge properly, and the uncertainties obtained are not realistic.

2) The single fault model with unconstrained position locates this structure some $15 \mathrm{~km}$ south of the actual Guaycume fault. This model presents the lowest uncertainties among the three.

3) The two-fault-model shows a good performance in the northern branch (corresponding to the Guaycume fault), but we obtain very high uncertainties on the computed values for the southern fault (that is located by the model $\sim 20 \mathrm{~km}$ south of Guaycume fault, coinciding with the southern border of the San Salvador graben).

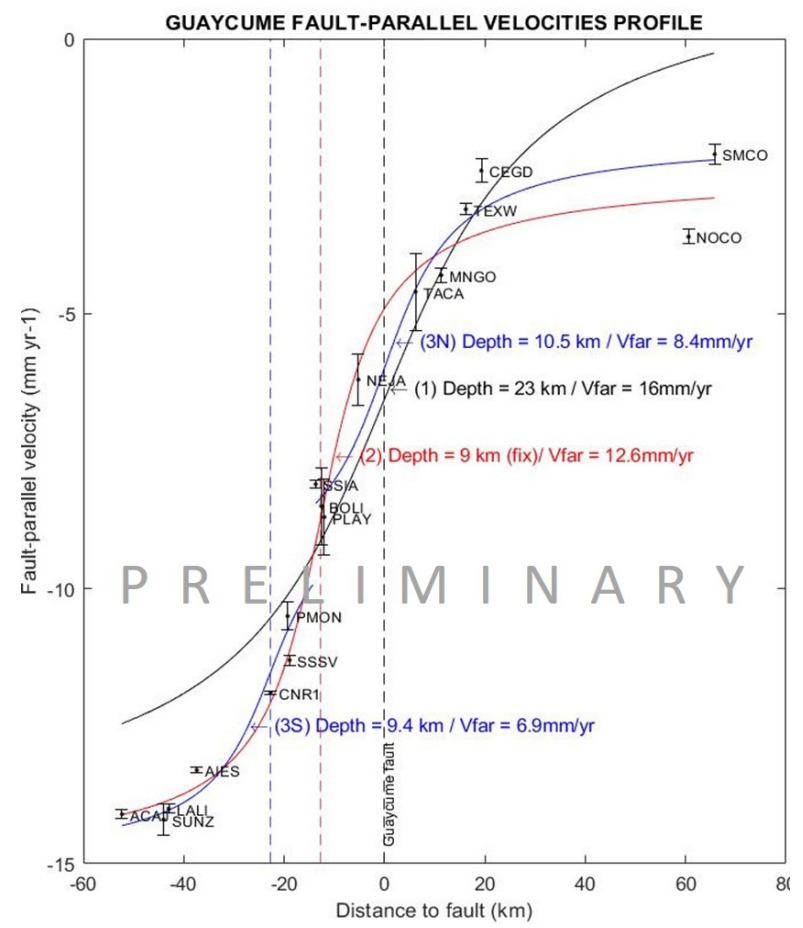

Figure 2: Guaycume fault-parallel velocity profile, showing the projected velocities as black dots (and their uncertainties as error bars) with respect to their distance to the Guaycume fault.

The three simple dislocation models that we fit are shown as

black 1), red 2) and blue 3) continuous lines. Dashed lines represent the central fault of each model (with their respective colours). Note that the model $3 \mathrm{~N}$ is centred on the black dashed line (the Guaycume fault). 


\section{Discussion and conclusions}

The lack of seismicity detected on the Guaycume fault surroundings may imply that the fault is heavily locked or presents an aseismic behaviour. Our data is not yet determinant to solve this question.

Following the same numbering as before, the models fitted to the fault-parallel velocity profile (Fig. 2) seem to indicate that:

1) The Guaycume fault does not seem to be the only structure accumulating the relative movement of the volcanic forearc, since this model does not even converge.

2) A single fault model (going through the San Salvador graben) fits the observations; however, this may be representing the complete movement of the forearc and not a single fault.

3) The two features model seems to be a feasible option, although the southern block is not well constrained (due to scarce observations). Additionally, it does not seem to explain the high velocity gradient within the San Salvador graben.

The behaviour of the Guaycume fault remains unclear, but it seems that it is not the only structure accumulating the forearc sliver migration. Furthermore, our data suggests that its slip rate is probably lower than the 8 $\mathrm{mm} / \mathrm{yr}$ estimated by Staller et al. (2016). This is consistent with the recent results of Legrand et al. (2020) on the San Salvador graben, which proposes that most of the deformation is accumulated further south from the Guaycume fault.

The lack of linearity and high dispersion on the GNSS time series of the stations located within San Salvador further complicates their tectonic interpretation. This can be clearly seen in Figure 3, where the north component accelerates since 2018. Volcano-tectonic interaction in the area is another key aspect that we must contemplate.

We will incorporate InSAR processing in the near future, focussing on L-Band ALOS data $(\lambda=23.6 \mathrm{~cm})$, which are more appropriate to deal with the forested areas of El Salvador. InSAR data, once properly corrected from atmospheric noise, will help us to better constrain the different deformation sources within the ESFZ, obtaining a continuous measurement of the ground deformation.

InSAR data and new GNSS observations will help us to close some of these gaps. In the future, we will extend this study to the remaining segments of the ESFZ, aiming to better determine the seismic hazard in El Salvador.
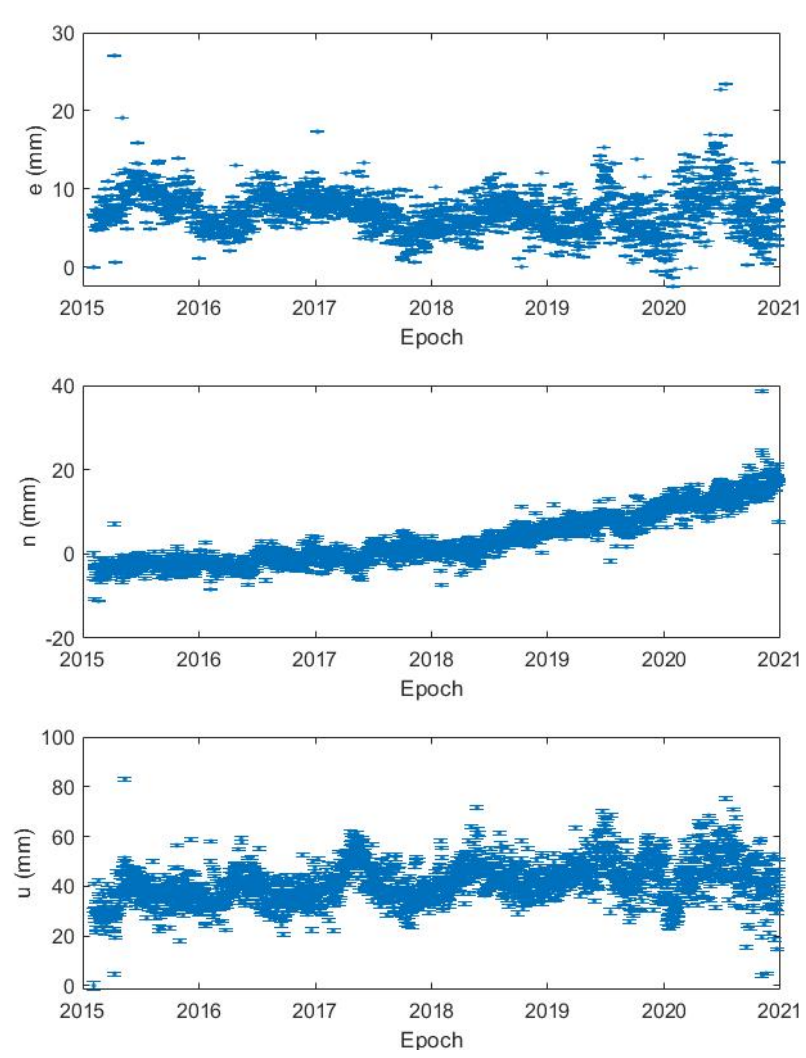

Figure 3: GNSS station "CNR1" e,n,u positioning time series for the period 2015-2020. Daily positions for each component are represented as blue dots with their standard deviations as error bars.

\section{Acknowledgements}

This work was supported by the Spanish Ministerio de Universidades (through the Formación del Profesorado Universitario program) under Grant FPU19/03929; and the Spanish Ministerio de Ciencia e Innovación under Grant CGL2017-83931-C3-3-P (GeoActiva project).

We thank the Salvadoran Ministerio de Medio Ambiente $y$ Recursos Naturales, especially Douglas Hernández, for providing data for this project.

We would also like to thank José Antonio Álvarez-Gómez, from the Universidad Complutense de Madrid, for his help with the seismic analysis and tectonic interpretation. We are grateful to the anonymous reviewers, who helped to improve the original article.

\section{References}

ALONSO-HENAR, J., BENITO, B., STALLER, A., ÁlVAREZ-GÓMEZ, J.A., MARTíNEZ-DÍAZ, J.J. and CANORA, C., 2018. Large-magnitude crustal seismic sources in El Salvador and deterministic hazard scenarios. Engineering Geology, 243, pp. 70-83. DOI: 10.1016/j.enggeo.2018.06.015.

ALONSO-HENAR, J., SCHREURS, G., MARTINEZ-DIAZ, J., ÁLVAREZ-GÓMEZ, J. and VILLAMOR, P., 2015. Neotectonic development of the El Salvador Fault Zone and implications for deformation in the Central America Volcanic Arc: Insights from 4-D analog modeling experiments. Tectonics, 34. DOI: 10.1002/2014TC003723.

ALTAMIMI, Z., REBISCHUNG, P., MÉTIVIER, L. and COLLILIEUX, X., 2016. ITRF2014: A new release of the International Terrestrial Reference Frame modeling nonlinear station motions. Journal of Geophysical Research: Solid Earth, 121(8), pp. 6109-6131. DOI: 10.1002/2016JB013098. 
ALVARADO, D., DEMETS, C., TIKOFF, B., HERNÁNDEZ, D., WAWRZYNIEC, T.F., PULLINGER, C., MATTIOLI, G., TURNER, H.L., RODRIGUEZ, M. and CORREA-MORA, F., 2011. Forearc motion and deformation between El Salvador and Nicaragua: GPS, seismic, structural, and paleomagnetic observations. Lithosphere, 3(1), pp. 3-21. DOI: 10.1130/L108.1.

ÁlVAREZ-GÓMEZ, J.A., MEIJER, P.T., MARTíNEZ-DÍAZ, J.J. and CAPOTE, R., 2008. Constraints from finite element modeling on the active tectonics of northern Central America and the Middle America Trench. Tectonics, 27(1). DOI: 10.1029/2007TC002162.

ÁlVAREZ-GÓMEZ, J., STALleR, A., MARTíNEZ-DíAZ, J., CANORA, C., ALONSO-HENAR, J., INSUA-ARÉVALO, J. and BEJAR, M., 2019. Push-pull driving of the Central America Forearc in the context of the Cocos-Caribbean-North America triple junction. Scientific Reports, 9. DOI: 10.1038/s41598-019-47617-3.

ARGUS, D.F., GORDON, R.G. and DEMETS, C., 2011. Geologically current motion of 56 plates relative to the no-netrotation reference frame. Geochemistry, Geophysics, Geosystems, 12(11). DOI: 10.1029/2011GC003751.

CANORA, C., 2011. Análisis sismotectónico, neotectónico y paleosísmico de la zona de falla de El Salvador, Centro América. PhD thesis. Universidad Complutense de Madrid.

CANORA, C., MARTINEZ-DIAZ, J., VILLAMOR, P., STALLER, A., BERRYMAN, K., ÁLVAREZ-GÓMEZ, J., CAPOTE, R. and DIAZ, M., 2014. Structural evolution of the El Salvador Fault Zone: An evolving fault system within a volcanic arc. Journal of Iberian Geology, 40, pp. 471-488. DOI: 10.5209/rev_JIGE.2014.v40.n3.43559.

CANORA, C., VILLAMOR, P., MARTINEZ-DIAZ, J., BERRYMAN, K., ÁlVAREZ-GÓMEZ, J., CAPOTE, R. and HERNÁNDEZ, W., 2012. Paleoseismic analysis of the San Vicente segment of the El Salvador Fault Zone, El Salvador, Central America. Geologica Acta, 10, pp. 103-123 DOI: 10.1344/105.000001700.

CHAVEZ HERNANDEZ, J.A., LAZECKÝ, M., ŠEBESTA, J. and BAKOŇ, M., 2020. Relation between surface dynamics and remote sensor InSAR results over the Metropolitan Area of San Salvador. Natural Hazards, 103(3), pp. 3661-3682. DOI: 10.1007/s11069-020-04150-1.

CORREA-MORA, F., DEMETS, C., ALVARADO, D., TURNER, H.L., MATTIOLI, G., HERNANDEZ, D., PULLINGER, C., RODRIGUEZ, M. and TENORIO, C., 2009. GPS-derived coupling estimates for the Central America subduction zone and volcanic arc faults: El Salvador, Honduras and Nicaragua. Geophysical Journal International, 179(3), pp. 12791291. DOI: 10.1111/j.1365-246X.2009.04371.x.

DACH, R., ANDRITSCH, F., ARNOLD, D., BERTONE, S., FRIDEZ, P., JÄGGI, A., JEAN, Y., MAIER, A., MERVART, L., MEYER, U., ORLIAC, E., GEIST, E., PRANGE, L., SCARAMUZZA, S., SCHAER, S., SIDOROV, D., SUSNIK, A., VILLIGER, A., WALSER, P. and THALLER, D., 2015. Bernese GNSS Software Version 5.2. ISBN 978-3-906813-059. DOI: $10.7892 /$ boris. 72297 .

DEMETS, C., 2004. Central America 2003/2004, UNAVCO, GPS/GNSS Observations Dataset. DOI: 10.7283/T5MG7MKZ DEMETS, C., 2007a. Central America 2006 - El Salvador, UNAVCO, GPS/GNSS Observations Dataset. DOI: 10.7283/T5T151RS

DEMETS, C., 2007b. Central America 2006 - Honduras, UNAVCO, GPS/GNSS Observations Dataset. DOI: 10.7283/T5P8491G

DEMETS, C., 2008a. Central America 2007 - El Salvador, UNAVCO, GPS/GNSS Observations Dataset. DOI: 10.7283/T5NC5Z91

DEMETS, C., 2008b. Central America 2007 - Honduras, UNAVCO, GPS/GNSS Observations Dataset. DOI: 10.7283/T5HM56KP

DEMETS, C., 2009. Central America 2008 - El Salvador, UNAVCO, GPS/GNSS Observations Dataset. DOI: 10.7283/T5CV4FVZ

DEMETS, C., 2011a. Honduras 2008, UNAVCO, GPS/GNSS Observations Dataset. DOI: 10.7283/T5GM85F9

DEMETS, C., 2011b. Honduras 2010, UNAVCO, GPS/GNSS Observations Dataset. DOI: 10.7283/T5736P0K

DEMETS, C. and TIKOFF, B., 2015a. Central America 2009 - El Salvador, UNAVCO, GPS/GNSS Observations Dataset. DOI: 10.7283/T58P5XT1

DEMETS, C. and TIKOFF, B., 2015b. Central America 2010 - El Salvador, UNAVCO, GPS/GNSS Observations Dataset. DOI: $10.7283 / \mathrm{T} 54 \mathrm{X} 5633$

DEMETS, C. and TIKOFF, B., 2015c. Central America 2012 - El Salvador, UNAVCO, GPS/GNSS Observations Dataset. DOI: 10.7283/T56Q1VHC

DEMETS, C. and TIKOFF, B., 2015d. Central America 2013 - El Salvador, UNAVCO, GPS/GNSS Observations Dataset. DOI: $10.7283 / T 5 Z 60 M C Z$

DEMETS, C. and TIKOFF, B., 2015e. Central America 2013 - Honduras, UNAVCO, GPS/GNSS Observations Dataset. DOI: 10.7283/T5PR7T97 
EBMEIER, S.K., BIGGS, J., MATHER, T.A. and AMELUNG, F., 2013. On the lack of InSAR observations of magmatic deformation at Central American volcanoes. Journal of Geophysical Research: Solid Earth, 118(5), pp. $2571-2585$. DOI: 10.1002/jgrb.50195

ELLIOTT, J.R., WALTERS, R.J. and WRIGHT, T.J., 2016. The role of space-based observation in understanding and responding to active tectonics and earthquakes. Nature Communications, 7(1), pp. 13844. Available from: https://doi.org/10.1038/ncomms13844 ISSN 2041-1723. DOI: 10.1038/ncomms13844

ELLIS, A., DEMETS, C., BRIOLE, P., COSENZA, B., FLORES, O., GRAHAM, S.E., GUZMÁN-SPEZIALE, M., HERNÁNDEZ, D., KOSTOGLODOV, V., LAFEMINA, P., LORD, N., LASSERRE, C., LYON-CAEN, H., RODRIGUEZ MARADIAGA, M., MCCAFFREY, R., MOLINA, E., RIVERA, J., ROGERS, R. and STALLER, A., 2018. GPS constraints on deformation in northern Central America from 1999 to 2017, Part 1 - Time-dependent modelling of large regional earthquakes and their post-seismic effects. Geophysical Journal International, 214(3), pp. 2177-2194. DOI: $10.1093 / g j i / g g y 249$

ELLIS, A., DEMETS, C., MCCAFFREY, R., BRIOLE, P., COSENZA MURALLES, B., FLORES, O., GUZMÁN-SPEZIALE, M., HERNÁNDEZ, D., KOSTOGLODOV, V., LAFEMINA, P., LORD, N., LASSERRE, C., LYON-CAEN, H., RODRIGUEZ MARADIAGA, M., MOLINA, E., RIVERA, J., ROGERS, R., STALLER, A. and TIKOFF, B., 2019. GPS constraints on deformation in northern Central America from 1999 to 2017, Part 2: Block rotations and fault slip rates, fault locking and distributed deformation. Geophysical Journal International, 218(2), pp. $729-754$. DOI:10.1093/gji/ggz173

GARIBALDI, N., TIKOFF, B. and HERNÁNDEZ, W., 2016. Neotectonic deformation within an extensional stepover in EI Salvador magmatic arc, Central America: Implication for the interaction of arc magmatism and deformation. Tectonophysics, 693, pp. 327-339. DOI: 10.1016/j.tecto.2016.05.015

INTERNATIONAL GNSS SERVICE, 2020. Network - International GNSS Service (igs.org). Available: https://www.igs.org/network/ [7/12, 2021].

INTERNATIONAL SEISMOLOGICAL CENTRE, 2021. ISC GEM Earthquake Catalogue. DOI: 10.31905/d.808.b.825

JIBSON, R., CRONE, A., HARP, E., BAUM, R., MAJOR, J., PULLINGER, C., ESCOBAR, C., MARTíNEZ, M. and SMITH, M., 2004. Landslides triggered by the 13 January and 13 February 2001 earthquakes in El Salvador. In: Natural Hazards in El Salvador, William I. Rose, Julian J. Bommer, Dina L. López, Michael J. Carr, Jon J. Major, pp. 69-88 ISBN 0-81372375-2. DOI: 10.1130/0-8137-2375-2.69

KOBAYASHI, D., LAFEMINA, P., GEIRSSON, H., CHICHACO, E., ABREGO, A.A., MORA, H. and CAMACHO, E., 2014. Kinematics of the western Caribbean: Collision of the Cocos Ridge and upper plate deformation. Geochemistry, Geophysics, Geosystems, 15(5), pp. 1671-1683. DOI: 10.1002/2014GC005234

LAFEMINA, P., DIXON, T.H., GOVERS, R., NORABUENA, E., TURNER, H., SABALLOS, A., MATTIOLI, G., PROTTI, M. and STRAUCH, W., 2009. Fore-arc motion and Cocos Ridge collision in Central America. Geochemistry, Geophysics, Geosystems, 10(5). DOI: https://doi.org/10.1029/2008GC002181

LEGRAND, D., MARROQUíN, G., DEMETS, C., MIXCO, L., GARCÍA, A., VILLALOBOS, M., FERRÉS, D., GUTIÉRREZ, E., ESCOBAR, D., TORRES, R. and HERNÁNDEZ, D., 2020. Active deformation in the San Salvador extensional stepover, El Salvador from an analysis of the April-May 2017 earthquake sequence and GPS data. Journal of South American Earth Sciences, 104, pp. 102854 DOI: 10.1016/j.jsames.2020.102854

LYON-CAEN, H., BARRIER, E., LASSERRE, C., FRANCO, A., ARZU, I., CHIQUIN, L., CHIQUIN, M., DUQUESNOY, T., FLORES, O., GALICIA, O., LUNA, J., MOLINA, E., PORRAS, O., REQUENA, J., ROBLES, V., ROMERO, J. and WOLF, R., 2006. Kinematics of the North American-Caribbean-Cocos plates in Central America from new GPS measurements across the Polochic-Motagua fault system. Geophysical Research Letters, 33(19). DOI:10.1029/2006GL027694

MARTÍNEZ-DÍAZ, J.J., ÁLVAREZ-GÓMEZ, J.A., STALLER, A., ALONSO-HENAR, J., CANORA, C., INSÚA-ARÉVALO, J.M., TSIGE, M., VILLAMOR, P., HERRERO-BARBERO, P., HERNÁNDEZ-MORENO, C., HERNÁNDEZ, W., HERNÁNDEZ, D., MARROQUÍN, G. and MIXCO, L., 2021. Active faults of El Salvador. Journal of South American Earth Sciences, 105, pp. 103038. DOI: 10.1016/j.jsames.2020.103038

MARTINEZ-DIAZ, J., ÁLVAREZ-GÓMEZ, J., BENITO, B. and HERNANDEZ, D., 2004a. Triggering of destructive earthquakes in El Salvador. Geology, 32, pp. 65-68 DOI: 10.1130/G20089.1

MARTINEZ-DIAZ, J., ÁLVAREZ-GÓMEZ, J., BENITO, B. and HERNANDEZ, D., 2004b. Triggering of destructive earthquakes in El Salvador. Geology, 32, pp. 65-68 DOI: 10.1130/G20089.1

NATIONAL GEODETIC SURVEY 2017. National Geodetic Survey - National Geodetic Survey (noaa.gov). Available: https://geodesy.noaa.gov/CORS/ [7/12, 2021].

REATH, K., PRITCHARD, M., POLAND, M., DELGADO, F., CARN, S., COPPOLA, D., ANDREWS, B., EBMEIER, S.K., RUMPF, E., HENDERSON, S., BAKER, S., LUNDGREN, P., WRIGHT, R., BIGGS, J., LOPEZ, T., WAUTHIER, C., MORUZZI, S., ALCOTT, A., WESSELS, R., GRISWOLD, J., OGBURN, S., LOUGHLIN, S., MEYER, F., VAUGHAN, G. and BAGNARDI, M., 2019. Thermal, Deformation, and Degassing Remote Sensing Time Series (CE 2000-2017) 
at the 47 most Active Volcanoes in Latin America: Implications for Volcanic Systems. Journal of Geophysical Research: Solid Earth, 124(1), pp. 195-218. DOI: 10.1029/2018JB016199

RODRÍGUEZ, M., DEMETS, C., ROGERS, R., TENORIO, C. and HERNANDEZ, D., 2009. A GPS and modelling study of deformation in northern Central America. Geophysical Journal International, 178(3), pp. 1733-1754. DOI: 10.1111/j.1365-246X.2009.04251.X

SANTAMARÍA-GÓMEZ, A., 2019. SARI: interactive GNSS position time series analysis software. GPS Solutions, 23(2), pp. 52. DOI: 10.1007/s10291-019-0846-y

SAVAGE, J.C. and BURFORD, R.O., 1973. Geodetic determination of relative plate motion in central California. Journal of Geophysical Research (1896-1977), 78(5), pp. 832-845. DOI: 10.1029/JB078i005p00832

STALLER, A., ÁLVAREZ-GÓMEZ, J., MARTINEZ-DIAZ, J. and BENITO, B., 2016. Present day kinematics of El Salvador Fault Zone.

STALlER, A., MARTINEZ-DIAZ, J., BENITO, B., HERNANDEZ, D., DÍAZ, M., PULLINGER, C., DEMETS, C., CANORA, C., ÁLVAREZ-GÓMEZ, J. and BEJAR, M., 2008. Red GPS "ZFESNET" para el estudio de la evolución del ciclo sísmico de deformaciones y esfuerzos asociado a la Zona de Falla de El Salvador.

UNAVCO, 2020. UNAVCO. Available: https://www.unavco.org/ [7/12, 2021]. 